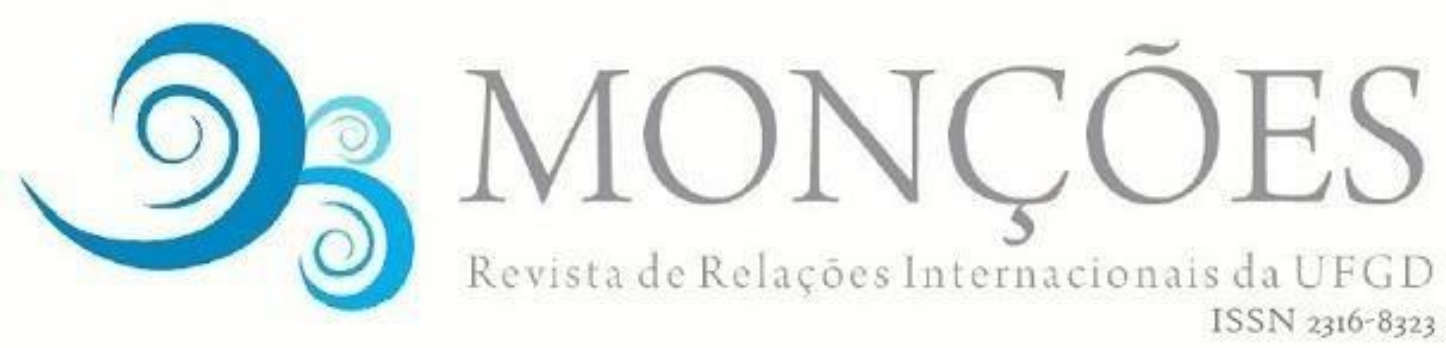

\title{
UNIVERSITIES AS PARADIPLOMATIC ACTORS IN THE BORDER REGIONS: A CASE STUDY ON THE BORDERS BETWEEN BRAZIL AND THE GUIANA REGION
}

PAULO GUSTAVO PELLEGRINO CORREA

$\mathrm{PhD}$ in Political Science. Professor of the International Relations course of the Federal University of Amapá - UNIFAP and of the Postgraduate Program in Border Studies of UNIFAP (PPGEF) and of the Postgraduate Program in Development of the Amazon of the Federal University of Roraima (PPGDRA). This researcher received support from the Pro-Defense (Edict 031-2013). Researcher of the Guiana Plateau Frontier

Observatory - OBFRON

TIAGO LUEDY SILVA

Specialist in International Relations. Professor of the International Relations course of the Federal University of Amapá - UNIFAP. Researcher of the International Relations and Geopolitics Laboratory - LABRIGEO

\begin{abstract}
This paper aims to discuss the role of Brazilian universities in the border region as paradiplomatic actors. It will be given a brief account of the concept of paradiplomacy, and then it will be discussed the limits, possibilities and potentialities of the international articulation of universities, mapping other important actors in this process. Finally, the discussion will be driven to a case study in northern Brazil: the Federal University of Amapá and the region of the Guianas.

KEYWORDS: Paradiplomacia; University; Region of Guyana.

\section{AS UNIVERSIDADES COMO ATORES PARADIPLOMÁTICOS NAS REGIÕES FRONTEIRIÇAS: UM ESTUDO DE CASO SOBRE AS FRONTEIRAS ENTRE O BRASIL E A REGIÃO DAS GUIANAS}

RESUMO: Este artigo tem como objetivo discutir o papel das universidades brasileiras nas regiões de fronteira como atores paradiplomáticos. Será feira uma breve exposição do conceito de paradiplomacia e em seguida serão discutidos os limites, as possibilidades e as potencialidades da articulação internacional das universidades, mapeando outros atores importantes nesse processo. Finalmente, a discussão será recortada para um estudo de caso no extremo norte do Brasil: a Universidade Federal do Amapá e região das Guianas.

PALAVRAS-CHAVE: Paradiplomacia; Universidade; Região das Guianas. 


\section{INTRODUCTION}

The international relations, as a rule, are conducted by the central power of the States. Ministries of foreign affairs, embassies, heads of state and diplomatic services form a fundamental part of the classical structure of the relationship between states and, in general, subnational agents are subordinated to the central government. However, since the end of the Cold War, when the international system came to be characterized by two non-antagonistic phenomena, globalization and regionalization, this reality of subordination has been altered.

Globalization, in general terms, is characterized by the great global flow of capital, people, ideas and values that overflow national borders. The importance of recognition of transnational entities, intergovernmental organizations and new international actors, in general, is a characteristic part of its premises. Regionalization, on the other hand, is a continuous cooperation on institutional bases between different actors in a given region in pursuit of mutual benefits in a context of deepening the interdependence between them. The practice of international relations in this context in which the international system presents itself as globalized and regionalized at the same time has undergone some transformations, notably in relation to the actors and the role they play in the global scene.

In these contemporary processes the borders have been re-signified and new actors have played an important role in international relations. It is not to say that the countries' foreign policy has ceased to have centrality. The change is in the possibility of subnational actors performing external actions with other international actors, including other subnational entities, in matters directly related to their respective interests.

One may think that the role played by subnational entities in international relations is a historical novelty. It is not. Panayotis Soldatos (1990) said that this phenomenon is not new, but that since the 1960s and 1970s, and especially in the last few decades, it has become possible to perceive a growing and increasingly intense participation of subnational actors in international relations. 
It is not only the globalization-regionalism binomial and the resulting political and economic impacts that serve to underpin the transformations mentioned above. Michael Keating (1997, p.31) argues that other features of the new world order such as multilateralism and the adoption of international regimes have shaped this new world reality that has diluted the distinction between internal and external affairs and has also re-defined the division of state and subnational actors responsibilities in the international and domestic context.

The roles and responsibilities acquired by subnational entities have been proved important in defining the strategic local interests that marked the external action on the region. Thinking the region and the locality from the region / locality itself was a powerful factor in transforming reality, since waiting for the central government to solve particularities did not always work.

This reality of "forgetting" local demands by central power was even more recurrent in the border regions. Despite the fact that the boundary between the national and the international is at the border, it is not necessarily there that the relationship between "us" and "them" is materialized. At least not until the emergence of the possibility of non-central actors, such as non-governmental organizations, companies and universities (besides states and municipalities) participating in international relations through an external action that became to be known as paradiplomacy.

\section{PARADIPLOMACY}

Guy Lachapelle and Stéphane Paquin (2005, p.9) argue that the neologism paradiplomacy emerged in the academic literature in the 1980 s to describe the international activities of the Canadian and American federal states in the context of the early modern globalization. About that, Maria Clotilde Ribeiro (2009, p.73) specifies that the term arose with the work of Panayotis Soldatos at the University of Montreal as opposed to an earlier concept, microdiplomacy, coined by lvo Duchacek at the University of New York.

Duchacek's concept of microdiplomacy (1990) was associated with the idea of "regional microdiplomacy", which was what he called the cross-border regional relations that took place between the United States and Canada and 
between the United States and Mexico in cities alongside the borders between these countries. After the terminological attack placed by Soldatos, Duchacek decided to use the term paradiplomacy to represent the international activities of subnational entities.

Duchacek's contribution to the development of the discussions around the term paradiplomacy, now accepted and used by both, was the distinction of two main categories of paradiplomacy: global and regional. The first one, global paradiplomacy, was the one in which the subnational actors turned to themes of the international scene; the other one, regional paradiplomacy, was the one in which the subjects had regional scope and interested to the actors of a certain region.

It was only in the late 1980s that the term paradiplomacy went on to encompass other possibilities beyond that of Soldatos and Duchacek dealt with. According to Farias (2000 apud RIBEIRO, 2009, p.74), it was Der Derian's ideas that broadened the use of the term paradiplomacy to any kind of international non-governmental activity conducted by non-state actors, including NGOs, transnational corporations, Scientific associations (in which the Universities are included) and even religious communities, among others.

Working on the concept of paradiplomacy in his book Foreign Relations and Federal States, Brian Hocking (1993, p.15) says that each author presents a description of paradiplomatic phenomena in a spectrum ranging from "a pale imitation of true and single diplomacy" (that one led by the States) to a lowintensity phenomenon which he called "second-order foreign policy".

Whether through subnational actors or other non-governmental actors, paradiplomacy has been an increasingly used practice in Brazil, but it is much more common in places such as Europe and North America, where many subnational actors (governmental or not) has its actions in international relations already established in a programmed way in its political agendas.

José Vicente da Silva Lessa points out that "paradiplomacy is explained as a deliberate policy of delegation of responsibilities in face of the increasing complexity of issues affecting border regions and the specificities of local interests" (LESSA, 2002, p.26). It happens, he says, because "central 
governments have often facing insufficient resources, knowedge and flexibility to account for those realities".

In his book "Paradiplomacia no Brasil e no mundo: o poder de celebrar tratados dos governos não centrais"1, Lessa emphasizes that the fields where paradiplomatic agreements in Brazil take place are: trade, industry, infrastructure, energy, shipbuilding, free trade areas, agro-industry, tourism, services, environment, public administration, legislative and electoral process, social policies, public finance, education, sports and culture, health and sanitation, science and technology and regional integration (LESSA, 2007, p.113) .

However, despite the wide range of themes covered by paradiplomacy, it is important to emphasize that none of them are part of the so-called high politics, that is, the structuring themes of the national political agenda (sovereignty, national security, macroeconomics, etc.).

\begin{abstract}
It is clear that subnational governments cannot have a foreign policy in the sense of high politics, but this does not prevent them, to a greater or lesser extent, according to the political system of which they are part of, to have a more or less articulated external action, that on certain occasions enters in the field of what is usually understood by foreign policy (SALAMÓN \& NUNES, 2007, p.103) ${ }^{2}$.
\end{abstract}

The authors of the paper in which the quote above was extracted from emphasize two concepts by James Rosenau in "Turbulence in World Politics" (1990) that helps to understand these actors: 1. Sovereignty-bound actors who are constrained by their sovereign responsibilities to a global agenda; 2 . Sovereignty-free actors who present less dispersed charges and seek to achieve more limited and concrete goals.

This second typology of actor linked to the subnational and paradiplomatic level in the external action helps us to understand the performance of the subject of this paper, the Universities. Even considering the fact that the Universities report directly to the central government, they have substantial autonomy to accomplish their more specific and concrete goals through international action,

\footnotetext{
${ }^{1}$ The book, not yet translated, can have its title understood as "Paradiplomacy in Brazil and in the world: the non-central government's power to enter into treaties". (Paper authors free translation to the book's title).

${ }^{2}$ Own translation.
} 
and in most cases they have these goals particularly related to their specificities and localities.

As seen earlier, although the main references in the study on paradiplomacy point out subnational governments usually as paradiplomatic agents, a broader approach on who are the subnational agents leads to the understanding that foreign affairs and their conduction through paradiplomacy need not be restricted only to government actors. Non-governmental organizations, political groups, political parties, educational and research institutions are also important actors in international relations and act - and may act - paradiplomaticly.

The institutional organization of these actors is often structured over exclusive sectors for international action such as advisories, departments or deputy vice-chancellor offices of international affairs. The building of such specific structures of international relations in the administrative apparatus, emphasizes Salomón \& Nunes (2007, p.105), shows the intensification of international action and also that they are willing to act in a more organized way.

\section{DIVERSIFICATION OF THE FOREIGN POLICY AGENDA: EDUCATION AND THE UNIVERSITIES}

The expansion of the international relations agenda is strengthened with the intensification of the globalization process. Classic themes such as economy and international security have kept a lot of space. However, new topics have begun to shape the relations between different actors in this new international scenario: social issues, environment, human rights, ethnic and religious conflicts, human trafficking, drugs, culture and education.

Concomitant with the expansion of the agenda, another important change in international relations was that with the end of bipolarity in the organization of world relations, the international system was decentralized, which strengthened the regional argument.

Generally the process of regionalization is associated with economic issues from regional integration and free trade agreements. However, the concept of regionalism in the last three decades has considerably expanded its 
scope, transcending the economy and comprising historical, political and cultural elements. Thus, education as a theme and universities as actors have an increasingly growth of participation in international relations, especially in regional relations (including as an instrument for strengthening integration).

During both terms of Lula da Silva's administration (2003-2010) and the first term of Dilma Rousseff's administration (2011-2014) in Brazil, the themes related to education, universities and foreign policy appeared in different ways. The Lula period strengthened Brazilian foreign policy in general, with emphasis on the surrounding geographical area. The actions towards Mercosur and Unasur are some of the initiatives that illustrate well this Brazilian focus in South America that have strengthened regionalism. In this process, education was, even if still timidly, part of the agenda. Initiatives such as bilingual education in schools in border regions, the creation of the Latin American University (UNILA) and the promotion of regional geography and history teaching were instruments that sought to strengthen regionalism through education.

During Dilma Rousseff's administration, for its turn, there was a retraction of the Brazilian international performance that could be perceived by the importance given to the Ministry of Foreign Affairs and especially to its budget. Nevertheless, it was during Rousseff administration that almost paradoxically began the largest educational internationalization program in Brazilian history, perhaps one of the largest in the world, Science Without Borders (SWB). In four years of SWB more than 100 thousand Brazilian students have been into universities of the five continents. Institutions that received few Brazilian students started to have hundreds or thousands of Brazilians in their facilities, having this group as a reality of their daily university life.

This process strengthened the internationalization of Brazilian education with distinct movements and to some degree universities as actors. In both administrations, Lula and Dilma, education linked to a foreign policy agenda had the strong presence of the Ministry of Education (MEC) in the development of programs. This Ministry, even with a limited degree of autonomy in foreign policy, has demonstrated the substantive impact of its presence on the content of politics (PINHEIRO \& BESHARA, 2012, p.154). 
It is important to add the impact on cooperation processes, since the internationalization of education, or more specifically the internationalization of the universities, strengthens this possibility. Alessandro Candeas preliminarily points out five different levels of agenda densities and institutionalization of educational cooperation: 1. High level of institutionalization, with a considerable exchange in post graduation; 2 . Intermediate level of institutionalization, with the expansion of interchange at various levels and a dense and complex agenda that demands increasing institutionalization; 3. Initial level of institutionalization, with strong potential for expansion and reciprocal interest; 4. Lower level of institutionalization, which deserves more attention, given its academic and scientific potential.

At these levels universities are pillar-like actors. However, it is fundamentally important to emphasize that when we deal with international action in the educational sector, we will be able to find within the subnational actors other sectors engaged in international action. And if we look more closely at the international action of local education actors in border regions, the focus of the case study of this paper, we can point out some important agents and sectors in paradiplomatic action.

With no pretension to present an exhaustively and conclusively list, it is listed below some agents and sectors related to education in the border region that play an essential role in international relations.

1. Teaching Institutions: schools, technical centers, colleges and universities in the closest region to the borders. The distance can range from none to some, which means being right on the border (in a twin city, for example) or located in cities close to the borders.

2. Consulates (Cons.): border regions usually have consulates of neighboring countries, especially in the larger cities, but in some federal states these consulates are in the capital city and not in a border town.

3. Embassies (Emb.): embassies are often related to the themes mentioned as high politics, leaving the everyday affairs to the consulates (even though they have little autonomy) - but their support can guarantee process fluency. 
4. Consuls: those responsible for consulates may have a direct involvement in actions in the border region. Despite their low decision-making autonomy, these actors are the direct link between the region with the embassies and central governments.

5. Ambassadors: those responsible for embassies are as important as their structure. They are responsible for several major decisions and the very fact of knowing about the action in progress can generate an important direct support to the action or an indirect support to the consulates.

6. Cultural Centers $(\mathrm{CC})$ : many embassies have the so-called "Cultural Centers". Brazil has approximately 20 Brazilian Cultural Centers (CCBs) around the world. Centers respond to the embassies and their activities are directly linked to education and culture.

7. Department of International Relations (SRI): many cities already have a sector to establish international actions. In some places these sectors are built as secretariats, but in some cases they can also be built as international advisory offices.

8. Department of Education (SE): educational actions not linked to higher education always go through their local department/secretariats. Schools have low decision-making autonomy, especially international decision-making. In this sense, local departments are fundamental agents in the actions.

9. Non-Governmental Organizations $\left(\mathrm{ONG}^{3}\right)$ : Many NGOs are linked to educational and cultural issues. The autonomy of these agents is one of their big advantages, and their flexibility for international action places them as important agents in the borders.

10. Development Agencies (AF): many national development agencies are somehow linked to funding research and they are also interested with the internationalization of higher education institutions. Thus, it is frequent to have public edicts promoting coordinate actions among international actors.

11. Research Institutions (IP): geographical proximity makes many research institutions to have similar themes of interest. This contributes for joint

\footnotetext{
${ }^{3}$ For the graphic image presenting the list of agents and sectors related to education in the border region that play an essential role in international relations, NGO's will be used in the Portuguese form: "ONG".
} 
actions to be developed by research institutions funded by development agencies.

12. International Organizations (Ol): international organizations can be seen as some sort of "international public space" that brings different actors together. Some of their various fields of interest are focused in education or related areas.

13. Migration-related organizations (OM): cross-border migration is part of the reality of the border regions. Its shapes vary widely, as well as the relationship established between the migratory group and the host society. It is quite common to find organizations that deal directly with migrant groups and they can be sometimes strong allies in projects related to education.

Figure 1: Agents linked to education in the border region

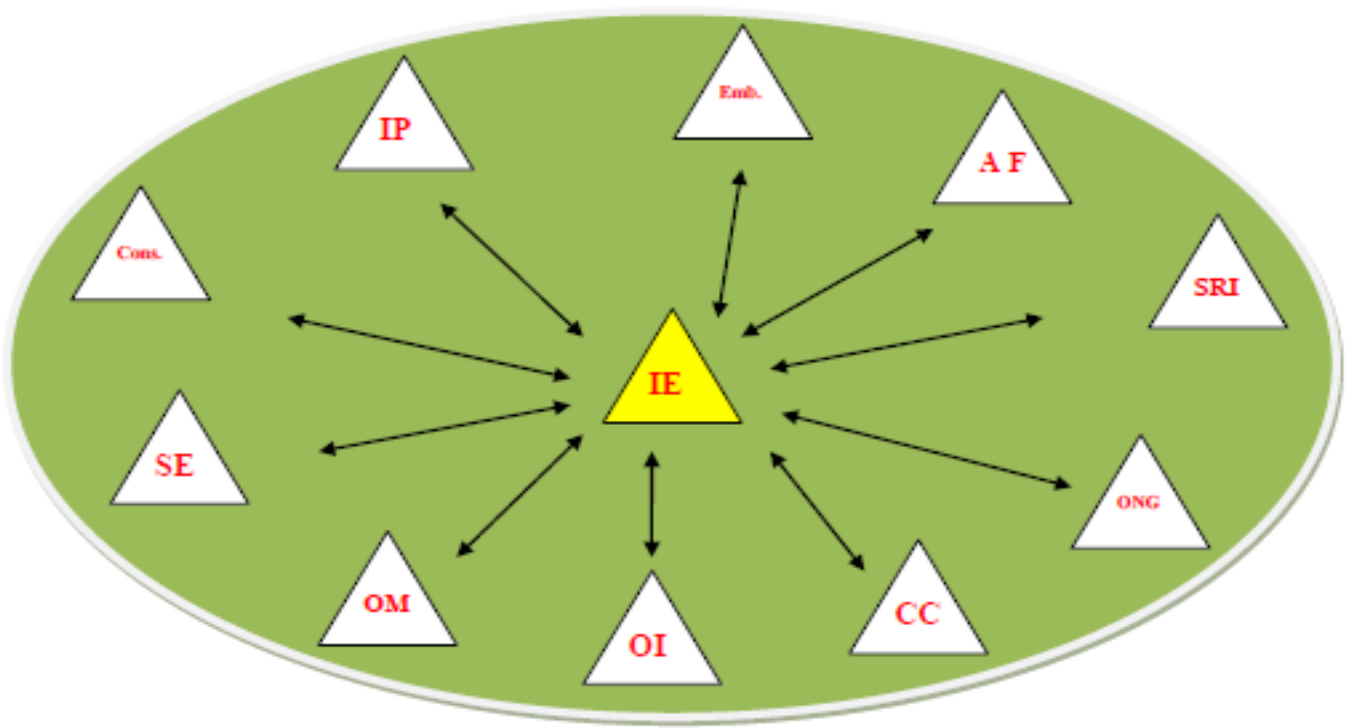

Source: CORREA \& ALVES, 2016, p.108.

\section{CASE STUDY: UNIFAP AND THE GUIANAS}

This case study is about the Federal University of Amapá (UNIFAP), which is located in the northern Amazon, in a state that is limited internationally through the municipalities of Oiapoque and Laranjal do Jari with French Guiana (a French Ultramarine Unit) and Suriname, respectively.

Amapá is the only Brazilian state without land connection with any other national state. In its geographical location there is a triple frontier in which the triborder area is characterized by low interconnectivity. The only terrestrial path for 
leaving Amapá is precisely towards French Guiana, which gives the region an internationalized characteristic since the beginning.

The places covered by UNIFAP's regular activities are marked by a peripheral location in relation to Brazil's the major centers, weakened by the aforementioned lack of land connection with the rest of the country. Nonetheless, Amapá is also characterized, at the same time, by its strategic condition due to its abundant natural resources and for being the path of Brazilian integration with northern South America and the Caribbean (as shown in the map below).

\section{Map 1: Guianas Plateau}

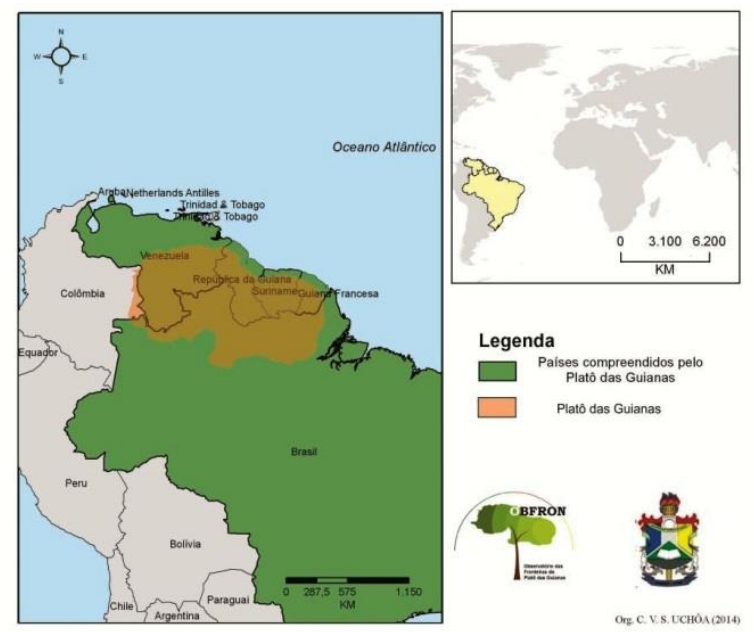

Source: CORREA, 2014.

Despite the local ethnical condition ${ }^{4}$ of Amapá, its historical and geographical backgrounds place internationality as an intrinsic element for the region and the internationalization of UNIFAP - as one of the main actors of human capital development in the state - as a strategic border project between the countries that make up the Guiana region (Brazil , France, Suriname, Guyana, and Venezuela). Therefore, UNIFAP is placed in an important scenario that brings to teaching, research and extension a great development, both in local/regional and international aspects.

\footnotetext{
${ }^{4}$ Ethnically speaking, Amapá is a state with a population composed by the strong presence of caboclos (mixed race between a white and an indian person) river communities and indigenous peoples of 5 different groups.
} 
The internationalization of a Higher Education Institution is the process of integrating an international and intercultural dimension into the teaching, research and extension functions. It should be a strategy of institutional change that leads to the development of a new culture where international, intercultural and interdisciplinary approaches are valued, thus enabling the promotion and support of initiatives for international interaction, cooperation and exchange programs.

Internally, the internationalization of a university is aimed at improving the quality, relevance and effectiveness of its teaching, research and extension. Externally, it is aimed at promoting its teaching and research potential, which is ultimately a key factor for the institution to participate in international higher education networks.

The mobility of students, teachers and managers substantially strengthens transnational ties, establishing connections and creating universal knowledge networks. These networks bring together academic communities from different parts of the world, reinforcing the premise that it is within the university that great scientific and technological advances must occur. It gives certain authority to scientific communities in the field of transnational contact because it is intrinsic in the academic life the international dimension that it should have.

UNIFAP is a young institution, but not so much, since it was created in the early 1990s. However, only recently through the process of the expansion of the university, in the last decade or so, and by means of a solid institutional project of internationalization, in the last few years, that this institution has become a university de facto.

Until 2014, the year that settles the beginning of the current management, UNIFAP had a low level of internationalization. Regarding international mobility, the number of international students within our institution was quite low, since there was only one systematic program of foreigner reception. The number of UNIFAP students in foreign institutions was also not very significant, even within the Science Without Borders Program (and these numbers did not become more significant regarding teaching exchange).

The lack of systematic offers of courses in other languages, the absence of a structure for receiving international students and teachers, and the 
insufficient institutional promotion of international mobility are some of the elements that made up a poor internationalization. Among the obstacles that were found in UNIFAP for its international action, it is possible to find:

- Ignorance of the idea of internationalization and the university as a possible paradiplomatic actor;

- Low importance attributed to international teaching and studying actions;

- Low number of bilingual students and teachers;

- Lack of an international culture at the university;

- Low number of international students in campus;

- Low institutional incentives for acting proactively in the international arena, especially in the surrounding geographical area.

To overcome this situation in order to become an international actor, UNIFAP has built an internationalization strategy. The attempt of rapprochement with the world's major research centers has been a constant action of the internationalization process in the last two years. The excellence centers are fundamental spaces for the academic community - technicians, students and teachers - to seek constant improvement. In that sense, the great universities were and are an intrinsic part of the international action of UNIFAP.

As a specific strategy it was highlighted the so-called Guiana Region as a major focus. The region differs from other parts of South America, among other reasons, for its linguistic diversity: besides the many spoken languages by traditional societies, we have in the same geographical space Portuguese (Brazil), Spanish (Venezuela), English (Guyana), Dutch (Suriname) and French (French Guiana) as well as the Creole languages. This diversity reflects the rich history of the region and its cultural multiplicity still to be explored by Brazilian universities. This has been an important factor that brought a great deal of difference to UNIFAP's international actions.

Integration projects such as the Initiative for the Regional Infrastructure Integration in South America (IIRSA), launched in 2000 aiming to connect the South American subcontinent - and present in the Guyana Plateau through a specific axis of integration and development - boost regional development. This process requires the participation of different development agents and the Universities are important actors to that end. In that sense, the very fact that 
UNIFAP focused its internationalization process in the Guianas region meant that it became a key actor in the region.

With the exception of Venezuela, all these territories are completely inserted within the Transnational Amazon and they are the natural path that links Brazil to the Caribbean, an area of great interest in contemporary Brazilian foreign policy, but still a "frontier" to explore. The relationship with the Caribbean Amazon can be the projection platform that Brazil needs to reach further to the Caribbean. In this way, it was understood that the relationship with this surrounding geographical environment had a great potential for constructing a proffering and differentiated international action for UNIFAP, which enables it to build itself as a paradiplomatic agent.

Another factor that have strongly collaborated to the regional acting of UNIFAP was the creation of a new campus in the city of Oiapoque. From 1999 to 2009, two programs were developed in the countryside of the state of Amapá aiming to train technicians and teachers from the state and municipal education structure. In 2007 a Full Degree in Indigenous School Education started. In 2013, seven undergraduation courses were opened in addition to the existing Indigenous Intercultural Degree.

The very name of the campus, Binational Campus of Oiapoque, sought to project an intrinsic internationality to it. However, the difficult local reality and the absence of a central government policies that actually would overcome the challenges meant that the campus would be "Binacional" only in the term. Even the proximity with the French Guiana (the city of Oiapoque is across the border to Saint-Georges, the municipality on the French side) was not enough to bring this international, or at least binational, character to the campus in its first years. But despite the long list of challenges that the Binational Campus in Oiapoque faces since it was created, it is a key element in the internationalization of UNIFAP.

\section{THE DEVELOPMENT OF THE INTERNATIONALIZATION PROJECT}

In order to build the international action of UNIFAP, the first measure was to strengthen the sector dedicated to cooperation and interinstitutional relations, the Deputy Vice-Chancellor Office of Cooperation and International Relations 
(PROCRI) through budget allocation, staff and institutional support in general. The next step was to map the agents and sectors related to education in the surrounding area, including the region border, that played a key role in international relations such as educational institutions, consulates, embassies, cultural centers, etc.

Once these agents were mapped the direct actions towards them had been initiated. At first with in loco missions of the Deputy Vice-Chancellor Officer as some sort of "university diplomat" through dozens of meetings in Guyana, Suriname and French Guiana. Later on, the actions were carried out by groups of teachers from different areas of knowledge, some kind of Committee, deepening the analysis on where the possibilities of cooperation would be.

This process resulted in the rapprochement of key players in UNIFAP's internationalization process. Down below a list of them:

- Université de Guyane (UG-GF);

- L'association D.A.A.C. Guyane ${ }^{5}$ (DAAC);

- Brazilian Consulate in Cayenne (CBC);

- French Consulate in Macapá (CFM) and French Embassy in Brazil (EFM);

- Observatoire Hommes-Milieux "Oyapock" (OHM);

- National Center for Scientific Research / Centre National de la Recherche Scientifique (CNRS);

- Research Institute for Development / Institut de la Recherche pour le Développement (IRD);

- Cayenne Prison Center (CPC);

- Representative of Brazilians in French Guiana (RBGF);

- Brazilian Embassy in Suriname (EBS);

- Anton de Kom University of Suriname (US);

- Brazil-Suriname Cultural Center (CCBS);

- SURIBRAS Foundation (SURIBRAS);

- Ministry of Education of Suriname (MES);

\footnotetext{
5 D.A.A.C. stands for Développement, Accompagnement, Animation, Coopération, which means Development, Accompaniment, Animation and Cooperation.
} 
- UNDP-Suriname (PNUD-S);

- Representative of the Brazilians in Suriname (RBS);

- Surinamese Embassy in Brazil (ESB);

- University of Guyana (UG-G);

- Brazilian Embassy in Guyana (EBG);

- Cultural Center Brazil-Guyana (CCBG).

Figure 2: Actors that make up the current framework of international action of UNIFAP

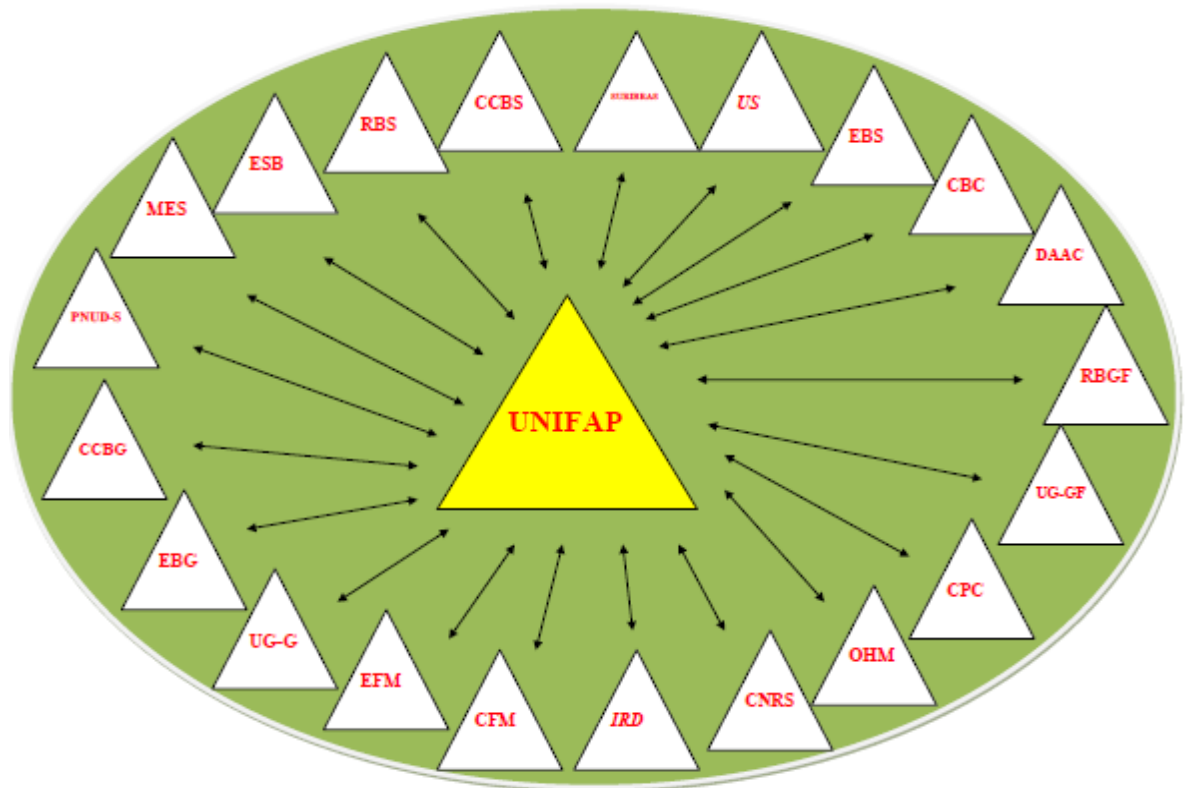

Source: own elaboration

In this set of agents the constant articulation is fundamental for the construction of a lasting relation. For that reason, Memoranda of Understanding (MOU) were signed with some institutions, mainly universities. However, the signing of these memoranda that could easily be shelved would not be enough, and thus the UNIFAP's strategy was and continues to be the promotion of internal edicts that fosters the relationship among regional international agents - and the idea is that these edicts would not be just a management policy, but also institutional programs that come to characterize the international action of UNIFAP. Down below some key edicts:

1. Call for researcher assistance for cross-border projects;

2. Call for student international mobility assistance; 
3. Call for researcher international mobility assistance;

4. Call for national academic mobility in Brazilian border regions assistance;

5. Call for mobility in Brazilian border regions assistance - Oiapoque;

6. Call for activities in the Brazil-Guyana Cultural Center assistance;

7. Call for researcher assistance for international mobility in the Guianas region;

8. Call for teachers technical committee selection (French Guiana and Suriname).

The promotion of these edicts gave the possibility for dozens of teachers and students to make some kind of academic mobility. From the resulting relations that were established between both parties a number of other projects were originated. Another very important factor that those edicts brought together with them was to give some place for the Guianas region in the imaginary of the academic community.

Not all this process is done without big challenges. The current national economic situation, the dollar exchange rate, and cuts in university budgets directly affect the internationalization project (of all Brazilian universities as a whole), even more in the smaller universities. Nevertheless, the minimal maintenance of edicts and the already established partnerships tend to keep the internationalization project sustained until better times for its deepening.

All these efforts in promoting the internationalization of the University brought results translated into regional and national recognition. In 2015 UNIFAP was invited to be part of the Brazil-France Joint Cross-Border Cooperation Meeting for discussing education". The invitation to participate in the "Nutrition for Growth Program" carried out by the Brazilian Ministry of Foreign Affairs was due not only to the proximity to the Caribbean but also because the role that UNIFAP has been playing in the region. Although those actions are still in an embryonic

\footnotetext{
${ }^{6}$ This participation in the Brazil-France Joint Cross-Border Cooperation Meeting led to another meeting of the Higher Education Institutions of Amapá in which a Forum of Academic Internationalization (to bring teaching institutions closer to each other in order to discuss their internationalization programs and projects) was created under UNIFAP leadership.
} 
phase they seem to demonstrate consistent possibilities to achieve very good results in the near future.

\section{CONCLUSION}

The dynamism of contemporary international relations in which emerged non-state actor in the international arena does not make a country's diplomacy to cease of being led by its central government, since themes of high politics are still the prerogative of the national State. Foreign relations, however, are not limited to these so-called high politics issues - thus, new actors have some space to play its roles.

Often the daily affairs of the cities and subnational states, especially the ones located in the border regions, make up an agenda that affects more directly the life of these communities than the foreign policy of the high state bureaucracy. In this sense, new local actors gain prominence in the construction of foreign relations in the most diverse subjects. As it was pointed out in the paper, there are several types of such agents, including universities.

Brazil is a country with thousands of miles of borders and marked socioeconomic-cultural diversity - a scenario where the universities close to the borders can take advantage to convert themselves into important paradiplomatic agents. In that case, these actors will be able to project their internationalization upon themes of their geographic surroundings and base their relations primarily with alike institutions resulting in a strengthened tripod of teaching, research and extension.

The case study presented about the Federal University of Amapá (UNIFAP) and the Guianas region indicates that systematic actions and projects can project the university as a paradiplomatic actor. This internationalization process that UNIFAP have been through in the last years is still in consolidation, but it has already presented some practical results such as a paradigmatic change in the local academic culture. 


\section{REFERENCES}

CORREA, Paulo Gustavo Pellegrino. As iniciativas de integração e segurança dos países amazónicos e o papel do Brasil neste contexto. 2014. 182 f. Tese (Doutorado) Curso de Ciência Política, Universidade Federal de São Carlos, São Carlos, 2014. CORREA, Paulo Gustavo Pellegrino \& ALVES, Mariana Janaina dos Santos. A Universidade Federal do Amapá em Oiapoque: Realidade, Potencialidades e Desafios da Educação na Fronteira Brasil-Guiana Francesa. Revista GeoPantanal, v. 11, p. 105115, 2016.

DUCHACEK, Ivo. Perforated sovereignties: toward a typology of new actors in international relations. In: MICHELMANN, H. \& SOLDATOS, P. Federalism and International Relations: the role of subnational units. New York: Oxford University Press, 1990.

HOCKING, Brian. Foreign Relations and Federal States. London: Leicester University Press, 1993.

KEATING, Michael. Regiones y Asuntos Internacionales: motivos, oportunidades y estrategias. In: ALDEDCOA, F. \& KEATING, M. (orgs.). Paradiplomacia: las relaciones internacionales de las regiones. Madrid: Marcial Pons, 1997.

LACHAPELLE, Guy \& PAQUIN, Stéphane. Mastering globalization: new sub-states' governance and strategies. London: Routledge, 2005.

LESSA, J. V. S. A paradiplomacia e os aspectos legais dos compromissos internacionais celebrados por governos não-centrais. Brasília: Ministério das Relações Exteriores, 2002.

Paradiplomacia no Brasil e no mundo: o poder de celebrar tratados dos governos não centrais. Viçosa - MG: Editora UFV, 2007. SALOMÓN, M. \& NUNES, C. A Ação Externa dos Governos Subnacionais no Brasil: Os Casos do Rio Grande do Sul e de Porto Alegre. Um Estudo Comparativo de Dois Tipos de Atores Mistos. Contexto Internacional, v. 29, p. 83-131, 2007.

SOLDATOS, Panayotis. La Nouvelle Génération de Villes Internationales: phénomène de segmentation des roles traditionnels de l'État-nation. Bruxelas: Bruylant, 1990.

RIBEIRO, Maria Clotilde. Globalização e Novos Atores: a paradiplomacia das cidades brasileiras. Salvador: EDUFBA, 2009.

ROSENAU, James. Turbulence in world politics. Princeton: Princeton University Press, 1990.

PINHEIRO, L. \& BESHARA, G. L. Política externa e educação: confluências e perspectivas no marco da integração regional. In: PINHEIRO, Leticia \& MILANI, Carlos Roberto Sanchez (Orgs.). Política externa brasileira: as práticas da política e a política das prática. Rio de Janeiro: Fundação Getulio Vargas, 2012, p. 149-180.

Recebido em 22 de agosto de 2017. Aprovado em 16 de janeiro de 2018. 